OPEN ACCESS

Edited by:

Pedro M. Pimentel-Coelho,

Federal University of Rio de Janeiro,

Brazil

Reviewed by:

Claire Rome,

Université Grenoble Alpes, France

Jialing Liu,

University of California,

San Francisco, United States

*Correspondence:

Oh Young Bang

ohyoung.bang@samsung.com

Specialty section:

This article was submitted to

Stroke,

a section of the journal

Frontiers in Neurology

Received: 16 December 2018

Accepted: 18 February 2019

Published: 12 March 2019

Citation:

Bang OY and Kim EH (2019) Mesenchymal Stem Cell-Derived Extracellular Vesicle Therapy for Stroke: Challenges and Progress.

Front. Neurol. 10:211.

doi: 10.3389/fneur.2019.00211

\section{Mesenchymal Stem Cell-Derived Extracellular Vesicle Therapy for Stroke: Challenges and Progress}

\author{
Oh Young Bang ${ }^{1,2 *}$ and Eun Hee Kim ${ }^{2,3,4}$ \\ ${ }^{1}$ Department of Neurology, Samsung Medical Center, Sungkyunkwan University School of Medicine, Seoul, South Korea, \\ ${ }^{2}$ Translational and Stem Cell Research Laboratory on Stroke, Samsung Medical Center, Seoul, South Korea, ${ }^{3}$ Medical \\ Research Institute, Sungkyunkwan University School of Medicine, Seoul, South Korea, ${ }^{4}$ Stem cell and Regenerative \\ Medicine Institute, Samsung Biomedical Research Institute, Seoul, South Korea
}

Stroke is the leading cause of physical disability among adults. Stem cells such as mesenchymal stem cells (MSCs) secrete a variety of bioactive substances, including trophic factors and extracellular vesicles (EVs), into the injured brain, which may be associated with enhanced neurogenesis, angiogenesis, and neuroprotection. EVs are circular membrane fragments $(30 \mathrm{~nm}-1 \mu \mathrm{m})$ that are shed from the cell surface and harbor proteins, microRNAs, etc. Since 2013 when it was first reported that intravenous application of MSC-derived EVs in a stroke rat model improved neurological outcomes and increased angiogenesis and neurogenesis, many preclinical studies have shown that stem cell-derived EVs can be used in stroke therapy, as an alternative approach to stem cell infusion. Although scientific research regarding MSC-derived EV therapeutics is still at an early stage, research is rapidly increasing and is demonstrating a promising approach for patients with severe stroke. MSC therapies have already been tested in preclinical studies and clinical trials, and EV-mediated therapy has unique advantages over cell therapies in stroke patients, in terms of biodistribution (overcoming the first pass effect and crossing the blood-brain-barrier), cell-free paradigm (avoidance of cell-related problems such as tumor formation and infarcts caused by vascular occlusion), whilst offering an off-the-shelf approach for acute ischemic stroke. Recently, advances have been made in the understanding of the function and biogenesis of EVs and EVs therapeutics for various diseases. This review presents the most recent advances in MSC-derived EV therapy for stroke, focusing on the application of this strategy for stroke patients.

Keywords: stroke, ischemic stroke, extracellular vesicles, stem cells, mesenchymal stem cells, microRNA

\section{INTRODUCTION}

Stroke is the leading cause of physical disability among adults. One-fourth to a half of stroke survivors are left with significant disabilities. Stem cell therapy is considered a potential regenerative strategy for patients with neurologic deficits. Adult stem cells, such as mesenchymal stem cells (MSCs) may be a good option for stroke therapy, as they secrete a variety of bioactive substances, including trophic factors and extracellular vesicles (EVs, $30 \mathrm{~nm}-1 \mu \mathrm{m}$ sized circular membrane fragments shed from the cell surface) into the injured brain, which is associated with enhanced 
neurogenesis, angiogenesis, and synaptogenesis (1-5). In addition, MSCs are thought to play multiple roles, such as attenuating inflammation (6), reducing scar thickness (7), enhancing autophagy (8), and possibly replacing damaged cells (9), in various brain diseases. Over the past 15 years, several randomized stem cell therapy trials have been conducted in patients with ischemic stroke (10-17), which showed mixed results. Possible reasons for conflicting results include, heterogeneous study populations (therefore requiring the selection of optimal candidate patients), delayed treatment (thus requiring an off-the shelf approach as soon as possible following a stroke), the limited restorative potential of stem cell therapy (especially in elderly patients with chronic illness), and a lack of objective measurements for the assessment of efficacy in stem cell therapy $(5,18)$.

It is widely accepted that MSCs exert their action via paracrine effects via secretomes or EVs, rather than through transdifferentiation to replace damaged neurons. Approximately $80 \%$ of cells disappeared in the infarcted brain within several days after transplantation with MSCs (19), yet the effects of stem cells persisted for several weeks following treatment. Our biodistribution study showed that MSCs exhibit a dynamic release of EVs in the ischemic brain condition, and that systemic administration of MSC-derived EVs led to a dose-dependent increase of MSC EVs in the infarcted hemisphere (bypassing the lung and liver) and functional improvement, suggesting that MSC EV therapy has a similar functional outcome, yet an improved safety profile compared to MSC administration (20).

This review presents the most recent advances in MSCderived EV therapy for stroke, focusing on the clinical application of this strategy for stroke patients.

\section{BIOLOGY AND FUNCTION OF EXTRACELLULAR VESICLES}

\section{EV Biogenesis}

EVs are a broad term that usually refers to heterogeneous vesicles that are released from cells. EVs containing cellular proteins, DNAs and RNAs of cells are classified into exosomes (30-200 nm), microvesicles (200-1000 nm) and apoptosomes (1$10 \mu \mathrm{m})$ depending on their size (21). Among them, exosomes and microvesicles released from living cells, are involved in many processes, such as proliferation, differentiation and angiogenesis, and are known to act as a means of intercellular communication (22-24).

Exosomes and microvesicles originate from the plasma membrane, and are formed through distinct mechanisms (Figure 1) (23). The generation of microvesicles begins with the recruitment of cytoplasmic proteins and nucleic acids by the endosomal sorting complex required for transport (ESCRT)-dependent and independent pathways \{mediated by ADP ribosylation factor 6 [ARF6] and phospholipase D2 [PLD2]. Lipid flipping then occurs, and membrane budding takes place.

Microvesicles are a more heterogeneous population and more sensitive to external stimulation than exosomes. For example, an increase in the extracellular concentration of ATP induces activation of the $\mathrm{P} 2 \mathrm{X} 7$ receptor and consequential release of microvesicles (21). The production of exosomes begins with the membrane folding inward, the creation of empty intraluminal vesicles (ILVs), and the maturation of ILVs into multivesicular bodies (MVBs). They are released into the extracellular space through fusion of MVBs and the plasma membrane by small GTPases, such as RAB27A, RAB11, and RAB35, or by ESCRT (25).

Knowledge regarding $\mathrm{EV}$ biogenesis is essential for understanding EV characteristics and for the development of EV therapeutics. For example, activation of P2X7R by the pathogen-associated molecular pattern (PAMP) or damageassociated molecular pattern (DAMP) can induce membrane blebbing, or fusion of MVBs. PLD2, which regulates lipids by degrading phosphatidylcholine into choline and phosphatidic acid, and ARF6, which regulates membrane trafficking and actin cytoskeleton remodeling, may play an important role in endocytosis and exocytosis (23). Studies have shown that overexpression of ARF6 increases the number of exosomes released from the cells, whereas inhibition of ARF6 and PLD2 reduces the release of exosomes $(26,27)$.

\section{Mechanisms of Action of Stem Cell-Derived EVs}

Stem cell-derived EVs could play a critical role in the exchange of information between stem cells and damaged cells and alter the behavior of the target cells. Ischemia induces an increase in the circulating or regional levels of EVs, and it has been identified that EVs have their own function. Stroke triggers the mobilization of bone marrow (BM) MSC-derived EVs in patients with severe stroke (28), and EVs released by ischemic stimulation have restorative capacity (20). In addition, EVs from ischemic tissue facilitated vasculogenesis in the ischemic limb model (29). EVs from ischemic muscles induce BM mononuclear cell differentiation into cells with an endothelial phenotype (29).

Formation of new neuronal cells and blood vessels are the fundamental processes for the recovery after ischemic brain injury. During acute phase of stoke, both ischemic/reperfusion injury and inflammatory response are pivotal to the pathophysiology of ischemic stroke. In addition, stroke patients are often elderly and have chronic diseases, which may attenuate regenerative potential after stroke. As shown in Table 1, regenerative potential could be enhanced by treatment of MSCs or MSC-derived EVs (67). In addition, treatment of MSC-derived EVs in animal models of brain diseases resulted in central and peripheral immunotolerance $(63,68)$. EVs harbor bioactive molecules and EVs secreted from stem cells carry more complex cargos than other cellular sources (69). Stem cell-derived EVs contain many molecules that may have therapeutic effects in stroke (70), such as microRNAs, proteins, and mitochondria (Table 1). MicroRNAs, are a class of short, single-stranded, non-coding RNAs that can be horizontally shuttled by EVs, and EVs-encapsulated proteins have been implicated in the regulation of protective and restorative processes (71). Beside microRNAs, MSC EVs may shuttle other genetic components, such as mRNAs (72). In addition, damage 


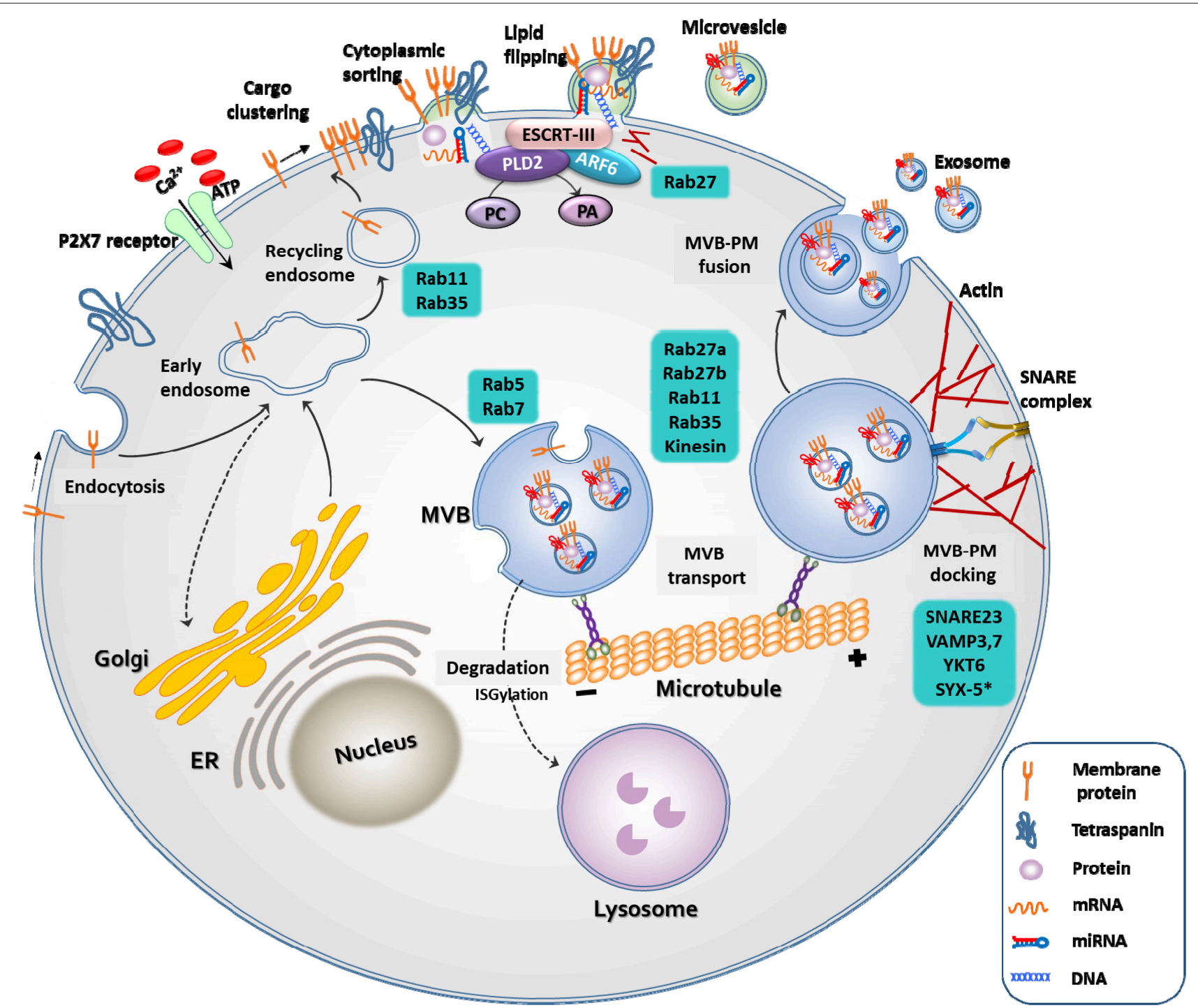

FIGURE 1 | Biogenesis of extracellular vesicles. EVs are released through two different pathways. When extracellular adenosine triphosphate (ATP) increases in response to external stimuli, the P2X7 receptor opens and calcium ions enter the cell. Membrane-associated proteins, tetraspanins, and cytoplasmic cargos are clustered in discrete membrane of the plasma membrane for microvesicles. The cargo of MVs are composed of cytoplasmic proteins, mRNAs, miRNAs, and DNAs. Similar to exosomes, RAS-related protein (RAB), actin, the endosomal sorting complex required for transport (ESCRT), ADP ribosylation factor 6 (ARF6) and phospholipase D2 (PLD2), and soluble N-ethylmaleimide-sensitive protein receptor (SNARE) proteins play important roles in MV release. However, MVs differ from exosomes in that they bud directly through flipping of lipid from the plasma membrane. The cargo of multivesicular bodies (MVBs) are either derived from endocytosis of the plasma membrane or from the trans-Golgi network. The reverse flow in the direction of the Golgi or recirculation to the plasma membrane is controlled by various Rab GTPases. Once MVB has matured, it is transported to the plasma membrane along the microtubule, and not by lysosomes. As a final step in exosome release, MVBs are docked and fused with the plasma membrane. Rab, actin, and SNARE proteins play important roles in these exosome release steps.

to the mitochondria caused by tissue injury, aggravates the severity of injury. Restoration of mitochondria dysfunction, through stem cell-derived mitochondria transplantation via EVs could potentially be an effective therapeutic strategy $(66,73)$.

\section{ADVANTAGES OF EXTRACELLUALR VESICLES OVER STEM CELLS IN STROKE}

Allogeneic stem cells have many advantages over autologous stem cells. Allogeneic MSCs are scalable from a manufacturing perspective, with standardized procedures. The use of allogeneic MSCs reduces the time required to obtain a sufficient number of cells (the "off the shelf" approach). Through the application of allogeneic stem cell therapy in the acute phase of stroke, both neurorestorative and neuroprotective actions can be expected (74). In recent clinical trials of intravenous application of allogeneic stem cells (MultiStem ${ }^{\circledR}$ in patients with acute stroke, stem cells were applied within 24-48 h, following the onset of symptoms (16). In addition, MSCs from younger healthy donors may differ in terms of their proliferation and neurorestorative 
TABLE 1 | Mode of action of stem cell-derived EV in animal models of stroke or other ischemic disease.

\begin{tabular}{|c|c|}
\hline Mode of action & Intravesicular contents \\
\hline $\begin{array}{l}\text { Angio-/neuro- } \\
\text { genesis }\end{array}$ & $\begin{array}{l}\text { miR-17-92 cluster targeting phosphatase and tensin } \\
\text { homolog (30) } \\
\text { miR-124a (31) } \\
\text { miR-126 targeting portocadherin } 7 \text { (32) } \\
\text { miR-133b targeting RABEPK (33) and RhoA (34) } \\
\text { miR-134 targeting caspase-8 (35) } \\
\text { miR-181b-5p targeting TRPM7 (36) } \\
\text { miR-184 targeting Numbl, miR-210 targeting ephrin-A3 } \\
\text { (20, 37, 38) } \\
\text { miR-210 targeting Efna3 (39) } \\
\text { miR-294 (40) } \\
\text { Angiopoietin-1 mRNA to restore vascular } \\
\text { permeability (41) } \\
\text { CXCR4 via Akt signaling pathway (42) } \\
\text { CXCR4, VEGF, VEGFR2, HGF, c-Met, Akt (20) } \\
\text { VEGF, HIF-1 } \alpha \text { (43) } \\
\text { PDGF (44) } \\
\text { ICAM-1, bFGF, CHI3L1, CD147, CD105 (37) } \\
\text { Transcription factors (STAT3) and signaling pathways } \\
\text { (NF-кB) (45, 46) } \\
\text { No specified (47-49) }\end{array}$ \\
\hline Neuroprotection & $\begin{array}{l}\text { miR-19a targeting PTEN (50) } \\
\text { miR-21 via MAPK signaling pathway (51) } \\
\text { miR-22 targeting Mecp2 (52) } \\
\text { miR-125b targeting p53 (53) } \\
\text { miR-145 targeting AQP4 (54) } \\
\text { miR-199a via sirt1 pathway (55) } \\
\text { miR-214 targeting CaMKII (56) } \\
\text { miR-494 via Akt pathway (57) } \\
\text { miR-711 targeting PPAR } \gamma(58) \\
\text { Neuron-specific enolase (59) } \\
\text { Plasminogen activator inhibitor-1 targeting STAT3 and } \\
\text { Akt (60) }\end{array}$ \\
\hline Immunomodulation & $\begin{array}{l}\text { miR-181a via BCL2, XIAP (61) } \\
\text { CD73 promote adenosine accumulation (62) } \\
\text { Anti-inflammatory cytokines (63) } \\
\text { Not specified (64) }\end{array}$ \\
\hline Rejuvenation & $\begin{array}{l}\text { miR-17, 34a via Akt signaling (65) } \\
\text { Mitochondria (66) }\end{array}$ \\
\hline $\begin{array}{l}\text { Thrombus } \\
\text { resolution and } \\
\text { recanalization }\end{array}$ & miR-126 targeting portocadherin 7 (32) \\
\hline
\end{tabular}

miR, microRNA; RABEPK, Rab9 effector protein with kelch motifs; RhoA, Ras homolog gene family member A; TRPM7, transient recent potential melastatin $7 ; N F-\kappa B$, nuclear factor- $\kappa B$; PDGF, platelet-derived growth factor.

capacity, from those obtained from elderly stroke patients with chronic illness (75).

However, conflicting results exist. Following serum contact, allogeneic MSCs can be injured by complement, and the viability of allogeneic MSCs after infusion is greatly reduced, compared with autologous MSCs (76). High mortality following intravenous transplantation of MSCs in animal stroke models, and reports of pulmonary embolism following intravenous injection of allogeneic adipose-derived MSCs have been accounted (77). MSC-related procoagulation status could be a possible explanation for such lethal pulmonary thromboembolism (78). Lastly, cell diameters of MSCs are large, ranging from 15 to $30 \mu \mathrm{m}$, which leads to passive arrest of MSCs in small diameter vessels, causing vascular occlusion and reduction in cerebral blood flow, when administered through intra-arterial routes, and also trapping in systemic vessels such as the lungs, when administered systemically (the first pass effect) (79-81).

The cell-free paradigm, using allogeneic MSC-derived EVs could avoid such cell-related problems of allogeneic stem cell therapy. EVs have low toxicity, high stability in the circulation, advantages in scalable production and storage, and high transport efficiency to donor cells (passing the blood-brain barrier [BBB] and avoiding the first pass effect).

\section{APPLICATIONS OF STEM CELL-EXTRACELLULAR VESICLES FOR TREATING STROKE \\ Preclinical Evidence of the Effects of EVs Derived From Various Stem Cells in Stroke}

Xin et al. reported for the first time, that intravenous application of MSC-derived EVs in a stroke rat model improved neurological outcomes and increased angiogenesis and neurogenesis (47). Other investigators have also demonstrated that stem cellderived EVs can be used for stroke therapy, as an alternative approach to stem cell infusion methods (Table 2) (67, 87, 88). In addition, several advances in EV-based strategy were introduced, including: (a) the use of stem cells other than MSCs, such as EVs from embryonic stem cells (ESCs), neural stem cells (NSCs), or induced pluripotent stem cells (iPSC)-derived MSC/NSCs (64, 84, 86), (b) application of EVs via the intra-nasal approach (84), (c) EV production other than conventional two-dimensional (2D) culture methods to increase the production of EVs and regulate the contents of EVs, e.g., 3D dynamic culture (37) and stimulation with ischemic brain extracts $(20,59)$, and (d) various EV isolation methods other than ultracentrifugation $(82,83,85)$. Very recently, the effects of EVs on stroke has been tested in a large animal model of stroke (86).

\section{Recent Advances for EV Therapeutics}

Various approaches are currently being employed to drive the MSC secretome toward a more anti-inflammatory and regenerative phenotype (88). Because secretomes include a wide array of growth factors, cytokines, and EVs, such approaches could also improve the efficacy of EV-based therapy.

Firstly, conventional 2D cell culture systems often disregard the mechanical stimuli that significantly influence the intricate in vivo cellular microenvironment. Characteristics of EVs as well as phenotypes of stem cells could be affected by mechanical forces (89). For example, shear stress enhances the immune regulatory function of MSCs (90). In addition, compared to conventional 2D cultured MSCs, MSCs cultured in spheroid showed higher efficacy and safety profiles, and decreased the expression of integrins, resulting in increased secretion of EVs $(91,92)$. Cha et al. successfully amplified EV sections and therapeutic EV contents (microRNAs and cytokines) from MSCs using a dynamic 3D culture method, 
TABLE 2 | Various applications of stem cell-derived EV in stroke.

\begin{tabular}{|c|c|c|c|c|c|}
\hline References & Animals & $\begin{array}{l}\text { Stem cells } \\
\text { /mode of application }\end{array}$ & $\begin{array}{l}\text { EV production } \\
\text { /culture media }\end{array}$ & $\begin{array}{l}\text { EV isolation } \\
\text { /dose per animal }\end{array}$ & Major finding \\
\hline Xin et al. (47) & Rat & $\begin{array}{l}\text { Rat BM MSCs } \\
\text { /intravenous }\end{array}$ & $\begin{array}{l}\text { 2D culture } \\
\text { /Exosome-free serum }\end{array}$ & $\begin{array}{l}\text { UC } \\
/ 100 \mu \mathrm{g} \text { total exosome protein }\end{array}$ & $\begin{array}{l}\text { Angiogenesis } \\
\text { Neurogenesis } \\
\text { Neurological recovery }\end{array}$ \\
\hline $\begin{array}{l}\text { Doeppner et al. } \\
\text { (82) }\end{array}$ & Mice & $\begin{array}{l}\text { Human BM MSCs } \\
\text { /intravenous }\end{array}$ & $\begin{array}{l}\text { 2D culture } \\
\text { /MSC basal media }\end{array}$ & $\begin{array}{l}\text { PEG } \\
\text { /EVs released by } 2 \times 10^{6} \text { cells }\end{array}$ & $\begin{array}{l}\text { Neuroprotection } \\
\text { Angiogenesis } \\
\text { Neurogenesis } \\
\text { Immunomodulation } \\
\text { Neurological recovery }\end{array}$ \\
\hline Chen et al. (83) & Rat & $\begin{array}{l}\text { Mini-pig adipose MSCs } \\
\text { /intravenous }\end{array}$ & $\begin{array}{l}\text { 2D culture } \\
/ 10 \% \text { fetal bovine serum }\end{array}$ & $\begin{array}{l}\mathrm{KISO}^{\mathrm{TM}} \text { system } \\
/ 100 \mu \mathrm{g} \text { total exosome protein }\end{array}$ & $\begin{array}{l}\text { Reduction of infarct volume } \\
\text { Neurological recovery }\end{array}$ \\
\hline Lee et al. (59) & Rat & $\begin{array}{l}\text { Human adipose MSCs } \\
\text { /intravenous }\end{array}$ & $\begin{array}{l}\text { 2D culture } \\
\text { /Serum free media with brain } \\
\text { extract }\end{array}$ & $\begin{array}{l}\text { UC } \\
/ 0.2 \mathrm{mg} \\
/ \mathrm{kg}\end{array}$ & $\begin{array}{l}\text { Angiogenesis } \\
\text { Neurogenesis } \\
\text { Immunomodulation }\end{array}$ \\
\hline Kalani et al. (84) & Mice & $\begin{array}{l}\text { Mice ESCs } \\
\text { /intra-nasal }\end{array}$ & $\begin{array}{l}\text { 2D culture on fibroblast } \\
\text { monolayer } \\
\text { /Exosome-free serum }\end{array}$ & $\begin{array}{l}\text { UC } \\
\text { /NA }\end{array}$ & $\begin{array}{l}\text { Restoration of } \\
\text { neurovascular unit } \\
\text { Immunomodulation }\end{array}$ \\
\hline $\begin{array}{l}\text { Otero-Ortega et al. } \\
\text { (85) }\end{array}$ & Rat & $\begin{array}{l}\text { Rat adipose MSCs } \\
\text { /intravenous }\end{array}$ & $\begin{array}{l}\text { 2D culture } \\
\text { /Exosome-free serum }\end{array}$ & $\begin{array}{l}\text { Exosome extraction kit } \\
\text { (miRCURY) } \\
/ 100 \mu \mathrm{g} \text { total exosome protein }\end{array}$ & $\begin{array}{l}\text { Neuroplasticity } \\
\text { White matter recovery } \\
\text { Neurological recovery }\end{array}$ \\
\hline Xin et al. (30) & Rat & $\begin{array}{l}\text { Rat BM MSCs } \\
\text { /intravenous }\end{array}$ & $\begin{array}{l}\text { 2D culture } \\
\text { /Exosome-free serum }\end{array}$ & $\begin{array}{l}\text { UC } \\
/ 100 \mu \mathrm{g} \text { total exosome protein }\end{array}$ & $\begin{array}{l}\text { Neuroplasticity } \\
\text { Neurological recovery }\end{array}$ \\
\hline Xin et al. (33) & Rat & $\begin{array}{l}\text { microRNA-133b } \\
\text { overexpressing Rat BM } \\
\text { MSCs } \\
\text { /intra-arterial }\end{array}$ & $\begin{array}{l}\text { 2D culture } \\
\text { /Exosome-free serum }\end{array}$ & $\begin{array}{l}\text { UC } \\
/ 3 \times 10^{11} \mathrm{EVs} \text {, comparable to } \\
100 \mu \mathrm{g} \text { total exosome protein }\end{array}$ & $\begin{array}{l}\text { Neuroplasticity } \\
\text { Neurological recovery }\end{array}$ \\
\hline Moon et al. (20) & Rat & $\begin{array}{l}\text { Rat BM MSCs } \\
\text { /intravenous }\end{array}$ & $\begin{array}{l}\text { 2D culture } \\
\text { /Serum free media with brain } \\
\text { extract }\end{array}$ & $\begin{array}{l}\text { UC } \\
/ 30 \mu \mathrm{g} \text { total exosome protein }\end{array}$ & $\begin{array}{l}\text { Angiogenesis Neurogenesis } \\
\text { Neuroplasticity Neurological } \\
\text { recovery }\end{array}$ \\
\hline Cha et al. (37) & In vitro & Human BM MSCs & $\begin{array}{l}\text { 3D dynamic culture } \\
\text { /Serum free media }\end{array}$ & $\begin{array}{l}\text { UC } \\
\text { /NA }\end{array}$ & $\begin{array}{l}\text { Angiogenesis } \\
\text { Neurogenesis } \\
\text { Neurological recovery }\end{array}$ \\
\hline Webb et al. (86) & Pig & $\begin{array}{l}\text { Human NSCs } \\
\text { /intravenous }\end{array}$ & $\begin{array}{l}\text { 2D culture } \\
\text { /NSC basal culture media }\end{array}$ & $\begin{array}{l}\text { UC } \\
/ 2 \times 10^{10} \mathrm{EVs} \\
/ \mathrm{kg}\end{array}$ & $\begin{array}{l}\text { Improve neural } \\
\text { tissue preservation } \\
\text { Neurological recovery }\end{array}$ \\
\hline Webb et al. (64) & Mice & $\begin{array}{l}\text { iPSC-derived NSC or MSCs } \\
\text { /intravenous }\end{array}$ & NA & NA & $\begin{array}{l}\text { Neuroprotection } \\
\text { Immunomodulation } \\
\text { Neurological recovery }\end{array}$ \\
\hline
\end{tabular}

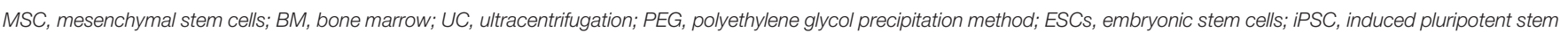
cell; NSCs, neural stem cells; NA, not available.

instead of using the conventional culture method (37). In a traumatic brain injury model, EVs derived from MSCs cultured in $3 \mathrm{D}$ scaffolds provided better outcomes than EVs from MSCs cultured in $2 \mathrm{D}$ conditions, probably by promoting neurogenesis and angiogenesis (93). Either native (decellularizing tissues) or synthetic 3D extracellular matrix-based scaffolds can be utilized to provide a 3D environment for cell attachment and growth (23).

Second, although MSC-derived EVs show promise in their application for regenerative therapies, their use is often limited by very low-yield conventional cell culture systems. Both microcarriers and hollow-fiber bioreactors are currently used for large-scale cell expansion of MSCs in the 3D environment (23) (89). These methods may be particularly useful in MSC EV production, because (a) large volumes of media would be required to get a sizable number of EVs for clinical use, (b) viability of MSCs could be maintained by continuous medium perfusion and avoiding metabolic by-product accumulation in a bioreactor, without the use of serum, which contains a large number of xenogeneic EVs, and (c) continuous processing, by controlling culture medium flow in and out of a bioreactor, as is often required because of the high advantages of reproducibility and safety of the resulting EV products.

Third, preconditioning of sublethal stimuli can trigger an adaptive response to further injury or damage. A wide variety of molecules and culture methods can be used to prime MSCs and modify their EVs. For example, Moon et al. showed that cultivation of MSCs with either serum obtained from stroke patients, or treatment of ischemic brain extracts on culture media, could activate restorative properties of MSCs and the release of EVs, suggesting that signals from an ischemic brain can affect the efficacy of MSCs and MSC-derived EVs and activate the secretion of EVs from MSCs $(20,94)$. Similar findings were also 
reported by another research group (59). It is widely accepted that hypoxic conditions (i.e., $0.1-2 \% \mathrm{O}_{2}$, conditions similar to $\mathrm{BM}$ ) were beneficial to MSCs and might stimulate MSCs to exhibit adaptive responses. MSC culture in hypoxic conditions with/without serum deprivation amplified EV sections, increased therapeutic EV contents (e.g., microRNAs), and improved the EV efficacy in tissue-injury models $(48,49,56,95)$. Inflammatory stimulation of MSCs renders release of EVs that have enhanced anti-inflammatory properties (96).

Fourth, as mentioned before, there have been advances in our current knowledge on the regulation of EV biogenesis (Figure 1). The modification of certain molecular pathways in EV biogenesis could lead to increased yield of EV production (23). For example, activation of EV biogenesis during membrane blebbing (P2X7 receptor, phospholipase D2) or multivesicular body fusion with the plasma membrane (Rab GTPase, SNARES) could increase EV secretion, leading to an increased yield (23, $25,97-100)$. In addition, genetic modification to overexpress certain therapeutic proteins or RNAs within EVs (Table 2) could lead to an increased efficacy of EVs. For example, EVs harvested from microRNA-133b-overexpressing MSCs improved neuronal plasticity and functional recovery following stroke (33). Furthermore, bioengineering techniques can be applied to produce semi-synthetic artificial EVs to increase the expression of functional/traceable molecules on EV surfaces/membranes or cargo, and fully synthetic artificial EVs can be engineered to increase the yield of EV production (101). For example, "exosome-like nanovesicles," which have morphological and biochemical characteristics similar to EVs, can be made from cells through cell membrane fragmentation (102).

Lastly, the source of EVs could be an important determinant in the efficacy of stem cell-derived EVs in stroke. MSCs have limited restorative potential in elderly patients. Similarly, MSC EVs may have significant age-dependent differences in their cargo contents (103). The transfer of EVs from young MSCs rejuvenated aged stem cells (65). Fetal MSCs from amniotic fluid, cord blood, or Wharton's Jelly-derived stem cells are reported to have intermediate cellular phenotypes between ESCs/iPSC and MSC, in terms of expression patterns of both marker/transcription factors of pluripotency and mesenchymal commitment, as well as their broadly multipotent nature (104). Although the use of ESC/iPSC-derived EV therapy may be safer than the use of ESC/iPSC cell therapy, in terms of tumorigenicity, limited data is available within the field of stroke and in human trials $(64,84)$. Therefore, fetal MSCs could be good sources of EVs in clinical application.

\section{CLINIAL APPLICATIONS OF EXTRACELLULAR VESICLE-BASED THERAPY}

The effects of EV therapeutics have increasingly been reported in various animal disease/injury models (87). However, only a few clinical studies on the effects of EV therapy have been reported in humans. Kordelas et al. reported a case study, whereby refractory graft-versus-host disease was treated with allogeneic MSC EVs (105). In this report, allogeneic MSCs were cultured in MSC conditioned media and EVs were isolated by the polyethylene glycol (PEG) precipitation method. EVs obtained from $4 \times 10^{7}$ MSCs were administered repetitively four times. Clinical symptoms were improved, and no adverse effects were observed. Katagiri et al. applied allogeneic MSC EVs via local injection for alveolar bone regeneration in eight patients who were diagnosed as needing bone augmentation prior to dental implant placement, which revealed this method was safe and may have great osteogenic potential (106). Lastly, Zhang et al. applied MSC EVs via intravitreal injection in five patients with refractory macular holes (107). All three clinical studies are small case series, and although this data suggests that MSC EVs are safe and may improve patient outcomes, randomization trials are needed to investigate the efficacy and safety of MSC EV therapy. No studies have examined the effects of stem cell-derived EVs in stroke patients. Several phase I/II clinical trials are ongoing to evaluate the application of EVs in cancer patients (108-110).

Considering MSC EVs are the therapeutically active component of MSCs, are non-self-replicating and small sized, the regulatory items required to produce $\mathrm{EV}$ fractions for clinical treatment strategies could be less complicated than for MSC therapies. However, compared to MSC therapy, clinical evaluation of EV therapeutics is still at an early stage. Several issues must be considered and need to be solved before the clinical application of EVs, including specific guidelines targeting EV-based therapeutics, characterization, isolation, and storage of EVs, quality control requirements, and in vivo analyses of EV. These issues were discussed precisely elsewhere $(87,111,112)$, yet the following issues deserve mention in the application of $\mathrm{EV}$ for stroke patients.

First, the optimal time and mode of application of EVs should be studied in stroke patients. Most recovery occurs in the first few months following a stroke, with only minor additional measureable improvements occurring thereafter. The levels of chemokines, trophic factors, and related miRNAs increase markedly in the infarcted brain during the acute phase of stroke but decrease over time. Such changes in the brain microenvironment may greatly affect the biodistribution of EVs, as well as the degree of recovery and neurogenesis/angiogenesis after EV therapeutics in stroke patients.

Second, since EVs have many therapeutic components and multiple modes of action, markers for potency and quality control should be chosen carefully and should be measured during the freezing/thawing procedures and storage period. EV therapeutics for stroke patients may differ depending on the time (acute vs. chronic phase) of application. For example, EV cargo components targeting neuroprotection and immunomodulation are needed in patients with acute ischemic stroke, while EV components targeting neurogenesis and angiogenesis are required for neurorestoration in both acute and chronic stroke patients. Differential markers for the potency of EVs (in vitro bioassays) may be needed for patients with acute and chronic ischemic stroke. In addition, customized stem cell-EV properties for stroke treatment are needed. Given the heterogeneity of EVs in terms of cargo proteins and RNAs, further studies are needed to increase the 
therapeutic components of EVs for stroke patients in clinically feasible ways $(33,37,56,96,113)$.

Lastly, the $\mathrm{BBB}$ is formed by the brain capillary endothelium and excludes $\sim 100 \%$ of large-molecule neurotherapeutics from the brain and more than $98 \%$ of all small-molecule drugs (114). As a result, compared with local application of EVs for topical diseases or other systemic illnesses, stroke patients often require large amounts of stem cells and stem cell-derived EVs. Therefore, selection of culture media and isolation methods are particularly important in EV therapeutics for stroke. Many different cell culture media have been used in the production of EVs, including serumsupplemented media, serum-free media, and EV-free/reduced serum-supplemented media. Because a prior elimination of EVs from fetal bovine serum is crucial, and commercial exosome/EV-depleted serum is expensive and may be imperfect, various methods to deplete EVs are being investigated, such as through the ultrafiltration method (115). In addition, various techniques have currently been used for $\mathrm{EV}$ isolation that include (but are not limited to) ultracentrifugation, PEG precipitation, size exclusion chromatography, and tangentialflow filtration. However, each method has advantages and disadvantages, and there is no reliable method for isolation techniques for EVs (112). Recently, GMP-compatible methods for clinical scale production, purification, and isolation of EVs have been introduced (116). Another important issue in improving the therapeutic effects of EV-based therapy in stroke is $\mathrm{BBB}$ manipulation, which may enhance endogenous repair mechanisms following stroke, by allowing entry of paracrine factors (e.g., trophic factors and EVs) more easily to the brain (117).

\section{CONCLUSION AND FUTURE PERSPECTIVES}

Cell therapy using EVs derived from stem cells could represent a new, clinically feasible, and cell-free paradigm that would avoid cell-related problems. Development of scientific research has just begun in this stem cell-derived EV strategy when compared to

\section{REFERENCES}

1. Chen X, Li Y, Wang L, Katakowski M, Zhang L, Chen J, et al. Ischemic rat brain extracts induce human marrow stromal cell growth factor production. Neuropathology. (2002) 22:275-9. doi: 10.1046/j.1440-1789.2002. 00450.x

2. Liu Z, Li Y, Zhang RL, Cui Y, Chopp M. Bone marrow stromal cells promote skilled motor recovery and enhance contralesional axonal connections after ischemic stroke in adult mice. Stroke. (2011) 42:740-4. doi: 10.1161/STROKEAHA.110.607226

3. Song M, Mohamad O, Gu X, Wei L, Yu SP. Restoration of intracortical and thalamocortical circuits after transplantation of bone marrow mesenchymal stem cells into the ischemic brain of mice. Cell Transplant. (2013) 22:200115. doi: 10.3727/096368912X657909

4. Lai RC, Chen TS, Lim SK. Mesenchymal stem cell exosome: a novel stem cell-based therapy for cardiovascular disease. Regen Med. (2011) 6:481-92. doi: $10.2217 /$ rme. 11.35 that of stem cell therapy. However, MSC-derived EV is rapidly expanding and could be a promising approach for patients with severe stroke, as MSC therapies have already been tested in preclinical and clinical trials and EV-mediated therapy has unique advantages over MSC therapies in stroke patients, in terms of biodistribution (cross the BBB and avoid the first pass effect) and off-the-shelf approaches for acute ischemic stroke.

There have been significant advances in the application of stem cell-derived EVs for human diseases and our understanding of the function and biogenesis of EVs. The efficacy of stem cell-derived EV therapeutics will be improved with advances in our understanding of the biology of stem cells and their EVs, together with advances in techniques to modulate stem cell-derived EV characteristics, including biotechnology and bioengineering. Future studies should focus on our need for more well-designed preclinical studies of EV therapeutics in animal models of stroke. Further studies should particularly focus on biodistribution studies, optimal time/dose/mode of application, and functional outcome measures with neuroimaging data. In addition, the optimal cargo of EVs for EV therapies for stroke patients is unsettled. Moreover, quality management of EVs and establishing standard operating procedures for EV therapeutics are needed, as randomized trials of EV for stroke patients are warranted.

\section{AUTHOR CONTRIBUTIONS}

$\mathrm{OB}$ and EK: study concept and design, acquisition of data, analysis and interpretation of data, drafting/revising the manuscript for content.

\section{FUNDING}

This research was supported by a grant from the Korean Healthcare Technology R\&D Project, Ministry of Health and Welfare (HI17C1256), and the Bio and Medical Technology Development Program of the National Research Foundation (NRF) funded by the Korean government (MSIT) (2018M3A9H1023675).
5. Bang OY, Kim EH, Cha JM, Moon GJ. Adult stem cell therapy for stroke: challenges and progress. J Stroke. (2016) 18:256-66. doi: $10.5853 /$ jos.2016.01263

6. Acosta SA, Tajiri N, Hoover J, Kaneko Y, Borlongan CV. Intravenous bone marrow stem cell grafts preferentially migrate to spleen and abrogate chronic inflammation in stroke. Stroke. (2015) 46:2616-27. doi: 10.1161/STROKEAHA.115.009854

7. Shen LH, Li Y, Chen J, Zacharek A, Gao Q, Kapke A, et al. Therapeutic benefit of bone marrow stromal cells administered 1 month after stroke. J Cereb Blood Flow Metab. (2007) 27:6-13. doi: 10.1038/sj.jcbfm.9600311

8. Shin JY, Park HJ, Kim HN, Oh SH, Bae JS, Ha HJ, et al. Mesenchymal stem cells enhance autophagy and increase beta-amyloid clearance in Alzheimer disease models. Autophagy. (2014) 10:32-44. doi: 10.4161/auto.26508

9. Yamauchi T, Kuroda Y, Morita T, Shichinohe H, Houkin K, Dezawa M, et al. Therapeutic effects of human multilineage-differentiating stress enduring (MUSE) cell transplantation into infarct brain of mice. PLoS ONE. (2015) 10:e0116009. doi: 10.1371/journal.pone.0116009 
10. Kondziolka D, Steinberg GK, Wechsler L, Meltzer CC, Elder E, Gebel J, et al. Neurotransplantation for patients with subcortical motor stroke: a phase 2 randomized trial. J Neurosurg. (2005) 103:38-45. doi: $10.3171 /$ jns.2005.103.1.0038

11. Lee JS, Hong JM, Moon GJ, Lee PH, Ahn YH, Bang OY, et al. A longterm follow-up study of intravenous autologous mesenchymal stem cell transplantation in patients with ischemic stroke. Stem Cells. (2010) 28:1099106. doi: $10.1002 /$ stem. 430

12. Kim SJ, Moon GJ, Chang WH, Kim YH, Bang OY, STARTING-2 (STem cell Application Researches and Trials In NeuroloGy-2) collaborators. Intravenous transplantation of mesenchymal stem cells preconditioned with early phase stroke serum: current evidence and study protocol for a randomized trial. Trials. (2013) 14:317. doi: 10.1186/1745-621514-317

13. Prasad K, Sharma A, Garg A, Mohanty S, Bhatnagar S, Johri S, et al. Intravenous autologous bone marrow mononuclear stem cell therapy for ischemic stroke: a multicentric, randomized trial. Stroke. (2014) 45:3618-24. doi: 10.1161/STROKEAHA.114.007028

14. Chen DC, Lin SZ, Fan JR, Lin CH, Lee W, Lin CC, et al. Intracerebral implantation of autologous peripheral blood stem cells in stroke patients: a randomized phase II study. Cell Transplant. (2014) 23:1599-612. doi: $10.3727 / 096368914 X 678562$

15. Ghali AA, Yousef MK, Ragab OA, ElZamarany EA. Intra-arterial infusion of autologous bone marrow mononuclear stem cells in subacute ischemic stroke patients. Front Neurol. (2016) 7:228. doi: 10.3389/fneur.2016. 00228

16. Hess DC, Wechsler LR, Clark WM, Savitz SI, Ford GA, Chiu D, et al. Safety and efficacy of multipotent adult progenitor cells in acute ischaemic stroke (MASTERS): a randomised, double-blind, placebo-controlled, phase 2 trial. Lancet Neurol. (2017) 16:360-8. doi: 10.1016/S1474-4422(17) 30046-7

17. Fang J, Guo Y, Tan S, Li Z, Xie H, Chen P, et al. Autologous endothelial progenitor cells transplantation for acute ischemic stroke: a 4-year follow-up study. Stem Cells Transl Med. (2018) 8:14-21. doi: 10.1002/sctm.18-0012

18. Bang OY. Stem cell therapy for stroke: lessons learned from recent successful randomized trials of interventional therapy for stroke. Precis Future Med. (2018) 2:109-16. doi: 10.23838/pfm.2018.00058

19. Rosenblum S, Wang N, Smith TN, Pendharkar AV, Chua JY, Birk H, et al. Timing of intra-arterial neural stem cell transplantation after hypoxiaischemia influences cell engraftment, survival, and differentiation. Stroke. (2012) 43:1624-31. doi: 10.1161/STROKEAHA.111.637884

20. Moon GJ, Sung JH, Kim DH, Kim EH, Cho YH, Son JP, et al. Application of mesenchymal stem cell-derived extracellular vesicles for stroke: biodistribution and microRNA study. Transl Stroke Res. (2018) 1-13. doi: 10.1007/s12975-018-0668-1. [Epub ahead of print].

21. Basso M, Bonetto V. Extracellular vesicles and a novel form of communication in the brain. Front Neurosci. (2016) 10:127. doi: $10.3389 /$ fnins.2016.00127

22. Burrello J, Monticone S, Gai C, Gomez Y, Kholia S, Camussi G. Stem cellderived extracellular vesicles and immune-modulation. Front Cell Dev Biol. (2016) 4:83. doi: 10.3389/fcell.2016.00083

23. Phan J, Kumar P, Hao D, Gao K, Farmer D, Wang A. Engineering mesenchymal stem cells to improve their exosome efficacy and yield for cell-free therapy. J Extracell Vesicles. (2018) 7:1522236. doi: 10.1080/20013078.2018.1522236

24. Todorova D, Simoncini S, Lacroix R, Sabatier F, Dignat-George F. Extracellular vesicles in angiogenesis. Circ Res. (2017) 120:1658-73. doi: 10.1161/CIRCRESAHA.117.309681

25. Colombo M, Raposo G, Thery C. Biogenesis, secretion, and intercellular interactions of exosomes and other extracellular vesicles. Annu Rev Cell Dev Biol. (2014) 30:255-89. doi: 10.1146/annurev-cellbio-101512-122326

26. Ghossoub R, Lembo F, Rubio A, Gaillard CB, Bouchet J, Vitale N, et al. Syntenin-ALIX exosome biogenesis and budding into multivesicular bodies are controlled by ARF6 and PLD2. Nat Commun. (2014) 5:3477. doi: $10.1038 /$ ncomms4477

27. Muralidharan-Chari V, Clancy J, Plou C, Romao M, Chavrier P, Raposo G, et al. ARF6-regulated shedding of tumor cell-derived plasma membrane microvesicles. Curr Biol. (2009) 19:1875-85. doi: 10.1016/j.cub.2009.09.059
28. Kim SJ, Moon GJ, Cho YH, Kang HY, Hyung NK, Kim D, et al. Circulating mesenchymal stem cells microparticles in patients with cerebrovascular disease. PLOS ONE. (2012) 7:e37036. doi: 10.1371/journal.pone. 0037036

29. Leroyer AS, Ebrahimian TG, Cochain C, Recalde A, BlancBrude O, Mees B, et al. Microparticles from ischemic muscle promotes postnatal vasculogenesis. Circulation. (2009) 119:2808-17. doi: 10.1161/CIRCULATIONAHA.108.816710

30. Xin H, Katakowski M, Wang F, Qian J, Lin XS, Ali MM, et al. MicroRNA-17-92 cluster in exosomes enhance neuroplasticity and functional recovery after stroke in rats. Stroke. (2017) 48:747-53. doi: 10.1161/STROKEAHA.116.015204

31. Yang J, Zhang X, Chen X, Wang L, Yang G. Exosome mediated delivery of miR-124 promotes neurogenesis after ischemia. Mol Ther Nucleic Acids. (2017) 7:278-87. doi: 10.1016/j.omtn.2017.04.010

32. Sun J, Zhang Z, Ma T, Yang Z, Zhang J, Liu X, et al. Endothelial progenitor cell-derived exosomes, loaded with miR-126, promoted deep vein thrombosis resolution and recanalization. Stem Cell Res Ther. (2018) 9:223. doi: 10.1186/s13287-018-0952-8

33. Xin H, Wang F, Li Y, Lu QE, Cheung WL, Zhang Y, et al. Secondary release of exosomes from astrocytes contributes to the increase in neural plasticity and improvement of functional recovery after stroke in rats treated with exosomes harvested from microRNA 133b-overexpressing multipotent mesenchymal stromal cells. Cell Transplant. (2017) 26:243-57. doi: 10.3727/096368916X693031

34. Holtje M, Djalali S, Hofmann F, Munster-Wandowski A, Hendrix S, Boato F, et al. A 29-amino acid fragment of clostridium botulinum C3 protein enhances neuronal outgrowth, connectivity, and reinnervation. FASEB J. (2009) 23:1115-26. doi: 10.1096/fj.08-116855

35. Xiao Y, Geng F, Wang G, Li X, Zhu J, Zhu W. Bone marrowderived mesenchymal stem cells-derived exosomes prevent oligodendrocyte apoptosis through exosomal miR-134 by targeting caspase-8. J Cell Biochem. (2018) doi: 10.1002/jcb.27519. [Epub ahead of print].

36. Yang Y, Cai Y, Zhang Y, Liu J, Xu Z. Exosomes secreted by adiposederived stem cells contribute to angiogenesis of brain microvascular endothelial cells following oxygen-glucose deprivation in vitro through microRNA-181b/TRPM7 axis. J Mol Neurosci. (2018) 65:74-83. doi: 10.1007/s12031-018-1071-9

37. Cha JM, Shin EK, Sung JH, Moon GJ, Kim EH, Cho YH, et al. Efficient scalable production of therapeutic microvesicles derived from human mesenchymal stem cells. Sci Rep. (2018) 8:1171. doi: 10.1038/s41598-018-19211-6

38. Liu C, Teng ZQ, Santistevan NJ, Szulwach KE, Guo W, Jin P, et al. Epigenetic regulation of miR-184 by MBD1 governs neural stem cell proliferation and differentiation. Cell Stem Cell. (2010) 6:433-44. doi: $10.1016 /$ j.stem.2010.02.017

39. Wang N, Chen C, Yang D, Liao Q, Luo H, Wang X, et al. Mesenchymal stem cells-derived extracellular vesicles, via miR-210, improve infarcted cardiac function by promotion of angiogenesis. Biochim Biophys Acta Mol Basis Dis. (2017) 1863:2085-92. doi: 10.1016/j.bbadis.2017.02.023

40. Khan M, Nickoloff E, Abramova T, Johnson J, Verma SK, Krishnamurthy $\mathrm{P}$, et al. Embryonic stem cell-derived exosomes promote endogenous repair mechanisms and enhance cardiac function following myocardial infarction. Circ Res. (2015) 117:52-64. doi: 10.1161/CIRCRESAHA.117.3 05990

41. Hu S, Park J, Liu A, Lee J, Zhang X, Hao Q, et al. Mesenchymal stem cell microvesicles restore protein permeability across primary cultures of injured human lung microvascular endothelial cells. Stem Cells Transl Med. (2018) 7:615-24. doi: 10.1002/sctm.17-0278

42. Kang K, Ma R, Cai W, Huang W, Paul C, Liang J, et al. Exosomes secreted from CXCR4 overexpressing mesenchymal stem cells promote cardioprotection via Akt signaling pathway following myocardial infarction. Stem Cells Int. (2015) 2015:659890. doi: 10.1155/2015/6 59890

43. Zou $\mathrm{X}, \mathrm{Gu} \mathrm{D}$, Xing $\mathrm{X}$, Cheng $\mathrm{Z}$, Gong $\mathrm{D}$, Zhang $\mathrm{G}$, et al. Human mesenchymal stromal cell-derived extracellular vesicles alleviate renal ischemic reperfusion injury and enhance angiogenesis in rats. Am J Transl Res. (2016) 8:4289-99. 
44. Ma J, Zhao Y, Sun L, Sun X, Zhao X, Sun X, et al. Exosomes derived from Akt-modified human umbilical cord mesenchymal stem cells improve cardiac regeneration and promote angiogenesis via activating platelet-derived growth factor D. Stem Cells Transl Med. (2017) 6:51-9. doi: 10.5966/sctm.2016-0038

45. Anderson JD, Johansson HJ, Graham CS, Vesterlund M, Pham MT, Bramlett $\mathrm{CS}$, et al. Comprehensive proteomic analysis of mesenchymal stem cell exosomes reveals modulation of angiogenesis via nuclear factor-kappaB signaling. Stem Cells. (2016) 34:601-13. doi: 10.1002/stem.2298

46. Shabbir A, Cox A, Rodriguez-Menocal L, Salgado M, Van Badiavas E. Mesenchymal stem cell exosomes induce proliferation and migration of normal and chronic wound fibroblasts, and enhance angiogenesis in vitro. Stem Cells Dev. (2015) 24:1635-47. doi: 10.1089/scd.2014.0316

47. Xin H, Li Y, Cui Y, Yang JJ, Zhang ZG, Chopp M. Systemic administration of exosomes released from mesenchymal stromal cells promote functional recovery and neurovascular plasticity after stroke in rats. J Cereb Blood Flow Metab. (2013) 33:1711-5. doi: 10.1038/jcbfm.2013.152

48. Zhang HC, Liu XB, Huang S, Bi XY, Wang HX, Xie LX, et al. Microvesicles derived from human umbilical cord mesenchymal stem cells stimulated by hypoxia promote angiogenesis both in vitro and in vivo. Stem Cells Dev. (2012) 21:3289-97. doi: 10.1089/scd.2012.0095

49. Bian S, Zhang L, Duan L, Wang X, Min Y, Yu H. Extracellular vesicles derived from human bone marrow mesenchymal stem cells promote angiogenesis in a rat myocardial infarction model. J Mol Med (Berl). (2014) 92:387-97. doi: 10.1007/s00109-013-1110-5

50. Yu B, Kim HW, Gong M, Wang J, Millard RW, Wang Y, et al. Exosomes secreted from GATA-4 overexpressing mesenchymal stem cells serve as a reservoir of anti-apoptotic microRNAs for cardioprotection. Int J Cardiol. (2015) 182:349-60. doi: 10.1016/j.ijcard.2014.12.043

51. Yao X, Wang Y, Zhang D. microRNA-21 confers neuroprotection against cerebral ischemia-reperfusion injury and alleviates blood-brain barrier disruption in rats via the MAPK signaling pathway. J Mol Neurosci. (2018) 65:43-53. doi: 10.1007/s12031-018-1067-5

52. Feng Y, Huang W, Wani M, Yu X, Ashraf M. Ischemic preconditioning potentiates the protective effect of stem cells through secretion of exosomes by targeting Mecp2 via miR-22. PLoS ONE. (2014) 9:e88685. doi: 10.1371/journal.pone.0088685

53. Xie YL, Zhang B, Jing L. MiR-125b blocks bax/cytochrome C/caspase3 apoptotic signaling pathway in rat models of cerebral ischemiareperfusion injury by targeting p53. Neurol Res. (2018) 40:828-37. doi: 10.1080/01616412.2018.1488654

54. Zheng L, Cheng W, Wang X, Yang Z, Zhou X, Pan C. Overexpression of microRNA-145 ameliorates astrocyte injury by targeting aquaporin 4 in cerebral ischemic stroke. Biomed Res Int. (2017) 2017:9530951. doi: 10.1155/2017/9530951

55. Xu WH, Yao XY, Yu HJ, Huang JW, Cui LY. Downregulation of miR-199a may play a role in 3-nitropropionic acid induced ischemic tolerance in rat brain. Brain Res. (2012) 1429:116-23. doi: 10.1016/j.brainres.2011.10.007

56. Wang Y, Zhao R, Liu D, Deng W, Xu G, Liu W, et al. Exosomes derived from miR-214-enriched bone marrow-derived mesenchymal stem cells regulate oxidative damage in cardiac stem cells by targeting CaMKII. Oxid Med Cell Longev. (2018) 2018:4971261. doi: 10.1155/2018/ 4971261

57. Wang X, Zhang X, Ren XP, Chen J, Liu H, Yang J, et al. MicroRNA494 targeting both proapoptotic and antiapoptotic proteins protects against ischemia/reperfusion-induced cardiac injury. Circulation. (2010) 122:130818. doi: 10.1161/CIRCULATIONAHA.110.964684

58. Zhao N, Mi L, Zhang X, Xu M, Yu H, Liu Z, et al. Enhanced MiR711 transcription by PPARgamma induces endoplasmic reticulum stress-mediated apoptosis targeting calnexin in rat cardiomyocytes after myocardial infarction. J Mol Cell Cardiol. (2018) 118:36-45. doi: 10.1016/j.yjmcc.2018.03.006

59. Lee JY, Kim E, Choi SM, Kim DW, Kim KP, Lee I, et al. Microvesicles from brain-extract-treated mesenchymal stem cells improve neurological functions in a rat model of ischemic stroke. Sci Rep. (2016) 6:33038. doi: $10.1038 /$ srep33038

60. Scheibe F, Klein O, Klose J, Priller J. Mesenchymal stromal cells rescue cortical neurons from apoptotic cell death in an in vitro model of cerebral ischemia. Cell Mol Neurobiol. (2012) 32:567-76. doi: 10.1007/s10571-012-9798-2

61. Xu LJ, Ouyang YB, Xiong X, Stary CM, Giffard RG. Post-stroke treatment with miR-181 antagomir reduces injury and improves long-term behavioral recovery in mice after focal cerebral ischemia. Exp Neurol. (2015) 264:1-7. doi: 10.1016/j.expneurol.2014.11.007

62. Amarnath S, Foley JE, Farthing DE, Gress RE, Laurence A, Eckhaus MA, et al. Bone marrow-derived mesenchymal stromal cells harness purinergenic signaling to tolerize human Th1 cells in vivo. Stem Cells. (2015) 33:1200-12. doi: 10.1002/stem.1934

63. Mokarizadeh A, Delirezh N, Morshedi A, Mosayebi G, Farshid AA, Mardani K. Microvesicles derived from mesenchymal stem cells: potent organelles for induction of tolerogenic signaling. Immunol Lett. (2012) 147:47-54. doi: 10.1016/j.imlet.2012.06.001

64. Webb RL, Kaiser EE, Scoville SL, Thompson TA, Fatima S, Pandya C, et al. Human neural stem cell extracellular vesicles improve tissue and functional recovery in the murine thromboembolic stroke model. Transl Stroke Res. (2018) 9:530-9. doi: 10.1007/s12975-017-0599-2

65. Kulkarni R, Bajaj M, Ghode S, Jalnapurkar S, Limaye L, Kale VP. Intercellular transfer of microvesicles from young mesenchymal stromal cells rejuvenates aged murine hematopoietic stem cells. Stem Cells. (2018) 36:420-33. doi: 10.1002/stem.2756

66. Wang J, Li H, Yao Y, Zhao T, Chen YY, Shen YL, et al. Stem cellderived mitochondria transplantation: a novel strategy and the challenges for the treatment of tissue injury. Stem Cell Res Ther. (2018) 9:106. doi: 10.1186/s13287-018-0832-2

67. Doeppner TR, Bahr M, Giebel B, Hermann DM. Immunological and nonimmunological effects of stem cell-derived extracellular vesicles on the ischaemic brain. Ther Adv Neurol Disord. (2018) 11:1756286418789326. doi: $10.1177 / 1756286418789326$

68. Laso-Garcia F, Ramos-Cejudo J, Carrillo-Salinas FJ, Otero-Ortega L, Feliu A, Gomez-de Frutos M, et al. Therapeutic potential of extracellular vesicles derived from human mesenchymal stem cells in a model of progressive multiple sclerosis. PLOS ONE. (2018) 13:e0202590. doi: 10.1371/journal.pone.0202590

69. Lai RC, Tan SS, Teh BJ, Sze SK, Arslan F, de Kleijn DP, et al. Proteolytic potential of the MSC exosome proteome: implications for an exosomemediated delivery of therapeutic proteasome. Int J Proteomics. (2012) 2012:971907. doi: 10.1155/2012/971907

70. Katsuda T, Ochiya T. Molecular signatures of mesenchymal stem cell-derived extracellular vesicle-mediated tissue repair. Stem Cell Res Ther. (2015) 6:212. doi: 10.1186/s13287-015-0214-y

71. Yuan Y, Du W, Liu J, Ma W, Zhang L, Du Z, et al. Stem cell-derived exosome in cardiovascular diseases: macro roles of micro particles. Front Pharmacol. (2018) 9:547. doi: 10.3389/fphar.2018.00547

72. Ragni E, Banfi F, Barilani M, Cherubini A, Parazzi V, Larghi P, et al. Extracellular vesicle-shuttled mRNA in mesenchymal stem cell communication. Stem Cells. (2017) 35:1093-105. doi: 10.1002/stem.2557

73. Hayakawa K, Chan SJ, Mandeville ET, Park JH, Bruzzese M, Montaner J, et al. Protective effects of endothelial progenitor cell-derived extracellular mitochondria in brain endothelium. Stem Cells. (2018) 36:1404-10. doi: 10.1002/stem.2856

74. Savitz SI. Cell therapies: careful translation from animals to patients. Stroke. (2013) 44:S107-9. doi: 10.1161/STROKEAHA.112.679605

75. Efimenko AY, Kochegura TN, Akopyan ZA, Parfyonova YV. Autologous stem cell therapy: how aging and chronic diseases affect stem and progenitor cells. Biores Open Access. (2015) 4:26-38. doi: 10.1089/biores.2014.0042

76. Li Y, Lin F. Mesenchymal stem cells are injured by complement after their contact with serum. Blood. (2012) 120:3436-43. doi: 10.1182/blood-2012-03-420612

77. Jung JW, Kwon M, Choi JC, Shin JW, Park IW, Choi BW, et al. Familial occurrence of pulmonary embolism after intravenous, adipose tissue-derived stem cell therapy. Yonsei Med J. (2013) 54:1293-6. doi: 10.3349/ymj.2013.54.5.1293

78. Tatsumi K, Ohashi K, Matsubara Y, Kohori A, Ohno T, Kakidachi H, et al. Tissue factor triggers procoagulation in transplanted mesenchymal stem cells leading to thromboembolism. Biochem Biophys Res Commun. (2013) 431:203-9. doi: 10.1016/j.bbrc.2012.12.134 
79. Krueger TEG, Thorek DLJ, Denmeade SR, Isaacs JT, Brennen WN. Concise review: mesenchymal stem cell-based drug delivery: the good, the bad, the ugly, and the promise. Stem Cells Transl Med. (2018) 7:651-63. doi: $10.1002 / \mathrm{sctm} .18-0024$

80. Pendharkar AV, Chua JY, Andres RH, Wang N, Gaeta X, Wang H, et al. Biodistribution of neural stem cells after intravascular therapy for hypoxicischemia. Stroke. (2010) 41:2064-70. doi: 10.1161/STROKEAHA.109.575993

81. Nguyen PK, Neofytou E, Rhee JW, Wu JC. Potential strategies to address the major clinical barriers facing stem cell regenerative therapy for cardiovascular disease: a review. JAMA Cardiol. (2016) 1:953-62. doi: 10.1001/jamacardio.2016.2750

82. Doeppner TR, Herz J, Gorgens A, Schlechter J, Ludwig AK, Radtke S, et al. Extracellular vesicles improve post-stroke neuroregeneration and prevent postischemic immunosuppression. Stem Cells Transl Med. (2015) 4:1131-43. doi: $10.5966 / \mathrm{sctm} .2015-0078$

83. Chen $\mathrm{KH}$, Chen $\mathrm{CH}$, Wallace CG, Yuen CM, Kao GS, Chen YL, et al. Intravenous administration of xenogenic adipose-derived mesenchymal stem cells (ADMSC) and ADMSC-derived exosomes markedly reduced brain infarct volume and preserved neurological function in rat after acute ischemic stroke. Oncotarget. (2016) 7:74537-56. doi: 10.18632/oncotarget.12902

84. Kalani A, Chaturvedi P, Kamat PK, Maldonado C, Bauer P, Joshua IG, et al. Curcumin-loaded embryonic stem cell exosomes restored neurovascular unit following ischemia-reperfusion injury. Int J Biochem Cell Biol. (2016) 79:360-9. doi: 10.1016/j.biocel.2016.09.002

85. Otero-Ortega L, Laso-Garcia F, Gomez-de Frutos MD, RodriguezFrutos B, Pascual-Guerra J, Fuentes B, et al. White matter repair after extracellular vesicles administration in an experimental animal model of subcortical stroke. Sci Rep. (2017) 7:44433. doi: 10.1038/srep 44433

86. Webb RL, Kaiser EE, Jurgielewicz BJ, Spellicy S, Scoville SL, Thompson TA, et al. Human neural stem cell extracellular vesicles improve recovery in a porcine model of ischemic stroke. Stroke. (2018) 49:1248-56. doi: 10.1161/STROKEAHA.117.020353

87. Fuster-Matanzo A, Gessler F, Leonardi T, Iraci N, Pluchino S. Acellular approaches for regenerative medicine: on the verge of clinical trials with extracellular membrane vesicles? Stem Cell Res Ther. (2015) 6:227. doi: 10.1186/s13287-015-0232-9

88. Cunningham CJ, Redondo-Castro E, Allan SM. The therapeutic potential of the mesenchymal stem cell secretome in ischaemic stroke. J Cereb Blood Flow Metab. (2018) 38:1276-92. doi: 10.1177/0271678X18 776802

89. Cha JM, Lee MY, Hong J. Bioreactor systems are essentially required for stem cell bioprocessing. Precis Future Med. (2018) doi: 10.23838/pfm.2018.00128. [Epub ahead of print].

90. Diaz MF, Vaidya AB, Evans SM, Lee HJ, Aertker BM, Alexander AJ, et al. Biomechanical forces promote immune regulatory function of bone marrow mesenchymal stromal cells. Stem Cells. (2017) 35:1259-72. doi: $10.1002 /$ stem. 2587

91. Xie L, Mao M, Zhou L, Jiang B. Spheroid mesenchymal stem cells and mesenchymal stem cell-derived microvesicles: two potential therapeutic strategies. Stem Cells Dev. (2016) 25:203-13. doi: 10.1089/scd.2015.0278

92. Mo M, Zhou Y, Li S, Wu Y. Three-dimensional culture reduces cell size by increasing vesicle excretion. Stem Cells. (2018) 36:286-92. doi: $10.1002 /$ stem. 2729

93. Zhang Y, Chopp M, Zhang ZG, Katakowski M, Xin H, Qu C, et al. Systemic administration of cell-free exosomes generated by human bone marrow derived mesenchymal stem cells cultured under $2 \mathrm{D}$ and $3 \mathrm{D}$ conditions improves functional recovery in rats after traumatic brain injury. Neurochem Int. (2017) 111:69-81. doi: 10.1016/j.neuint.2016.08.003

94. Moon GJ, Cho YH, Kim DH, Sung JH, Son JP, Kim S, et al. Serum-mediated activation of bone marrow-derived mesenchymal stem cells in ischemic stroke patients: a novel preconditioning method. Cell Transplant. (2018) 27:485-500. doi: 10.1177/0963689718755404

95. Park H, Park H, Mun D, Kang J, Kim H, Kim M, et al. Extracellular vesicles derived from hypoxic human mesenchymal stem cells attenuate gsk3beta expression via miRNA-26a in an ischemia-reperfusion injury model. Yonsei Med J. (2018) 59:736-45. doi: 10.3349/ymj.2018.59.6.736
96. Harting MT, Srivastava AK, Zhaorigetu S, Bair H, Prabhakara KS, Toledano Furman NE, et al. Inflammation-stimulated mesenchymal stromal cellderived extracellular vesicles attenuate inflammation. Stem Cells. (2018) 36:79-90. doi: 10.1002/stem.2730

97. Qu Y, Dubyak GR. P2X7 receptors regulate multiple types of membrane trafficking responses and non-classical secretion pathways. Purinergic Signal. (2009) 5:163-73. doi: 10.1007/s11302-009-9132-8

98. Urbanelli L, Magini A, Buratta S, Brozzi A, Sagini K, Polchi A, et al. Signaling pathways in exosomes biogenesis, secretion and fate. Genes (Basel). (2013) 4:152-70. doi: 10.3390/genes4020152

99. Rao SK, Huynh C, Proux-Gillardeaux V, Galli T, Andrews NW. Identification of SNAREs involved in synaptotagmin VII-regulated lysosomal exocytosis. $J$ Biol Chem. (2004) 279:20471-9. doi: 10.1074/jbc.M400798200

100. Hsu C, Morohashi Y, Yoshimura S, Manrique-Hoyos N, Jung S, Lauterbach MA, et al. Regulation of exosome secretion by Rab35 and its GTPase-activating proteins TBC1D10A-C. J Cell Biol. (2010) 189:223-32. doi: $10.1083 /$ jcb. 200911018

101. Garcia-Manrique P, Matos M, Gutierrez G, Pazos C, Blanco-Lopez MC. Therapeutic biomaterials based on extracellular vesicles: classification of bio-engineering and mimetic preparation routes. J Extracell Vesicles. (2018) 7:1422676. doi: 10.1080/20013078.2017.1422676

102. Yoon J, Jo W, Jeong D, Kim J, Jeong H, Park J. Generation of nanovesicles with sliced cellular membrane fragments for exogenous material delivery. Biomaterials. (2015) 59:12-20. doi: 10.1016/j.biomaterials.2015. 04.028

103. Fafian-Labora J, Lesende-Rodriguez I, Fernandez-Pernas P, SangiaoAlvarellos S, Monserrat L, Arntz OJ, et al. Effect of age on pro-inflammatory miRNAs contained in mesenchymal stem cell-derived extracellular vesicles. Sci Rep. (2017) 7:43923. doi: 10.1038/srep43923

104. Loukogeorgakis SP, De Coppi P. Concise review: amniotic fluid stem cells: the known, the unknown, and potential regenerative medicine applications. Stem Cells. (2017) 35:1663-73. doi: 10.1002/stem.2553

105. Kordelas L, Rebmann V, Ludwig AK, Radtke S, Ruesing J, Doeppner TR, et al. MSC-derived exosomes: a novel tool to treat therapy-refractory graft-versushost disease. Leukemia. (2014) 28:970-3. doi: 10.1038/leu.2014.41

106. Katagiri W, Osugi M, Kawai T, Hibi H. First-in-human study and clinical case reports of the alveolar bone regeneration with the secretome from human mesenchymal stem cells. Head Face Med. (2016) 12:5. doi: 10.1186/s13005-016-0101-5

107. Zhang X, Liu J, Yu B, Ma F, Ren X, Li X. Effects of mesenchymal stem cells and their exosomes on the healing of large and refractory macular holes. Graefes Arch Clin Exp Ophthalmol. (2018) 256:2041-52. doi: 10.1007/s00417-018-4097-3

108. Escudier B, Dorval T, Chaput N, Andre F, Caby MP, Novault S, et al. Vaccination of metastatic melanoma patients with autologous dendritic cell (DC) derived-exosomes: results of thefirst phase I clinical trial. J Transl Med. (2005) 3:10. doi: 10.1186/1479-5876-3-10

109. Dai S, Wei D, Wu Z, Zhou X, Wei X, Huang H, et al. Phase I clinical trial of autologous ascites-derived exosomes combined with GM-CSF for colorectal cancer. Mol Ther. (2008) 16:782-90. doi: 10.1038/mt.2008.1

110. Morse MA, Garst J, Osada T, Khan S, Hobeika A, Clay TM, et al. A phase I study of dexosome immunotherapy in patients with advanced non-small cell lung cancer. J Transl Med. (2005) 3:9. doi: 10.1186/1479-5876-3-9

111. Lener T, Gimona M, Aigner L, Borger V, Buzas E, Camussi G, et al. Applying extracellular vesicles based therapeutics in clinical trials - an ISEV position paper. J Extracell Vesicles. (2015) 4:30087. doi: 10.3402/jev.v4.30087

112. Reiner AT, Witwer KW, van Balkom BWM, de Beer J, Brodie C, Corteling RL, et al. Concise review: developing best-practice models for the therapeutic use of extracellular vesicles. Stem Cells Transl Med. (2017) 6:1730-9. doi: $10.1002 /$ sctm.17-0055

113. Domenis R, Cifu A, Quaglia S, Pistis C, Moretti M, Vicario A, et al. Pro inflammatory stimuli enhance the immunosuppressive functions of adipose mesenchymal stem cells-derived exosomes. Sci Rep. (2018) 8:13325. doi: 10.1038/s41598-018-31707-9

114. Pardridge WM. Blood-brain barrier drug targeting: the future of brain drug development. Mol Interv. (2003) 3:90-105. doi: 10.1124/mi.3.2.90

115. Kornilov R, Puhka M, Mannerstrom B, Hiidenmaa H, Peltoniemi $\mathrm{H}$, Siljander $\mathrm{P}$, et al. Efficient ultrafiltration-based protocol to deplete 
extracellular vesicles from fetal bovine serum. J Extracell Vesicles. (2018) 7:1422674. doi: 10.1080/20013078.2017.1422674

116. Watson DC, Yung BC, Bergamaschi C, Chowdhury B, Bear J, Stellas D, et al. Scalable, cGMP-compatible purification of extracellular vesicles carrying bioactive human heterodimeric IL-15/lactadherin complexes. J Extracell Vesicles. (2018) 7:1442088. doi: 10.1080/20013078.2018.1442088

117. Borlongan CV, Hadman M, Sanberg CD, Sanberg PR. Central nervous system entry of peripherally injected umbilical cord blood cells is not required for neuroprotection in stroke. Stroke. (2004) 35:2385-9. doi: 10.1161/01.STR.0000141680.49960.d7
Conflict of Interest Statement: The authors declare that the research was conducted in the absence of any commercial or financial relationships that could be construed as a potential conflict of interest.

Copyright $\odot 2019$ Bang and Kim. This is an open-access article distributed under the terms of the Creative Commons Attribution License (CC BY). The use, distribution or reproduction in other forums is permitted, provided the original author(s) and the copyright owner(s) are credited and that the original publication in this journal is cited, in accordance with accepted academic practice. No use, distribution or reproduction is permitted which does not comply with these terms. 